PF 2019 (LXXIV): 155-161

\author{
ADRIANA FERENČÍKOVÁ \\ Jazykovedný ústav Ludovíta Štúra Slovenskej akadémie vied \\ Panská 26, 81101 Bratislava \\ tel. +421254431762 \\ e-mail: adriana.ferencikova@juls.savba.sk
}

\title{
NIEKTORÉ TYPY NEZHODNÉHO PRÍVLASTKU V SLOVENSKÝCH NÁREČIACH*
}

\begin{abstract}
KLƯČOVÉ SLOVÂ: slovenské nárečia, syntaktický výskum, jazykový atlas, lingvistická geografia.
\end{abstract}

SŁOWA KLUCZOWE: dialekty słowackie, badania składni, atlas językowy, geografia lingwistyczna.

KEYWORDS: Slovak dialects, syntactic research, language atlas, areal linguistics.

\section{SOME TYPES OF APPOSITIONAL ADJECTIVE IN THE SLOVAK DIALECTS}

\begin{abstract}
The project named The Atlas of the Slovak Language is supposed to be completed by volume, which will reveal geographical differences in appropriate syntax. The method of reliable field data collection has proved unsuccessful when researching the syntax of dialects. An undistorted picture of systematic elements in dialectal syntax can be obtained through analyses of complex dialectal texts representing the entire Slovak language territory. This method facilitates not only resuming those syntactical structures which are typical for dialectal speech, but also ascertaining their frequency in comparison with equal units. This approach is recommended also for collected initial materials serving as base for the syntactic volume of the Atlas. Researching several particular types of the infinitive attribute, as well as the appositional attribute with verbal substantive which are components of the syntactic system of a great part of the Slovak dialects, but which, nevertheless, had not found their way into literary language, we have decided to use an analysis of complex dialectal texts.
\end{abstract}

* Príspevok je súčastou riešenia projektu VEGA 2/0104/18 Slovanský jazykový atlas - odraz prirodzeného vývinu jazyka. 
Podla autora koncepcie Atlasu slovenského jazyka (ASJ) Jozefa Štolca má tento projekt zavŕšit osobitný - piaty - syntaktický zväzok. Jeho základným poslaním má byt ozrejmenie vztahu slovenskej syntaxe k syntaxi iných slovanských jazykov (pozri SStolc 1967). Azda aj preto do Inventára syntaktických javov v slovenských nárečiach, pomocou ktorého sa majú získavat terénne údaje, syntaktik Ján Oravec zaradil vyše 200 otázok. No už overovanie použitelnosti Inventára pri terénnom výskume jednoznačne ukázalo, že v rozhodujúcej väčšine sledovaných javov nemožno získat spolahlivú informáciu odpovedou na priamu otázku a že metóda navodenia situácie, v ktorej by informátor spontánne použil náležitú nárečovú formu stvárnenia skúmaného syntaktického vztahu, je rovnako neefektívna. Terénna skúsenost’ s Inventárom len potvrdila názor J. Štolca, že metóda výskumu nárečovej syntaxe sa musí podstatne odlišovat od metódy výskumu iných jazykových rovín. Podla jeho mienky treba východiskové údaje pre kartografické spracovanie syntaktických javov čerpat zo súvislých nárečových textov alebo ich zachytávat zo spontánnych prehovorov nositelov miestnych nárečí. $S$ ohladom na fakt, že takýto postup velmi predlžuje fázu zhromaždenia komplexného východiskového materiálu, Štolc navrhol, aby sa vybrané syntaktické javy postupne spracúvali na celom slovenskom jazykovom území formou monografií a štúdií a z mapových príloh $\mathrm{k}$ takýmto prácam by sa neskôr mohol zostavit syntaktický zväzok $\mathrm{ASJ}^{1}$. Tento postup by zároveň umožnil zachytit aj rovnoznačné syntaktické konštrukcie $\mathrm{v}$ systéme jedného nárečového celku a naznačit ich miesto na osi základné, bežné, zriedkavé, archaické. Pravda, geografický rozsah syntaktických javov nemožno vymedził tak presne, ako je to pri fonetických, morfologických, lexikálnych či slovotvorných javoch, no aj primeranými kartografickými prostriedkami vyjadrená informácia, že na časti územia národného jazyka je vyskyt istej syntaktickej konštrukcie kompaktný, kým inde sú doklady na ňu rozptýlené či sporadické alebo je neznáma, má pre dialektológický a historický výskum jazyka nezanedbatel’nú výpovednú hodnotu.

Bohaté texty v archíve dialektologického oddelenia Jazykovedného ústavu Ludovíta Štúra SAV v súčasnosti už umožňujú sledovat vybrané syntaktické javy na celom slovenskom jazykovom území2. O terénne údaje získané excerpciou $\mathrm{z}$ tohto fondu a $\mathrm{z}$ dialektologickej literatúry sa opierame aj pri sondačnom výskume výskytu konštrukcií s nezhodným atribútom vyjadreným infinitívom a s nezhodným atribútom so substantívom verbale.

1 Otázky súvisiace s výskumom syntaxe slovenských nárečí J. Štolc podrobnejšie rozobral v príspevku Výsledky, perspektívy a problémy slovenskej dialektológie, „Slovenská reč”, t. XXXII, s. $216-224$.

$2 \mathrm{Z}$ tohto zdroja sme čerpali materiál pri výskume typov časových viet - pozri Ferenčíková 1986. 
Podla zistenia Jozefa Ružičku (1958) býva v spisovnej slovenčine infinitívny prívlastok pri abstraktných substantívach, „ktorými sa vyjadruje vôla alebo rozhodnutie, povinnost' alebo potreba, možnost' alebo nemožnost', schopnost' alebo neschopnost', právo, príčina a zvyk konat' dej vyslovený pripojeným slovesom v neurčitku“ (Ružička 1958: 155). Takéto spojenia sú vo všetkých nárečiach. Na ilustráciu uvádzame po jednom doklade zo stred., záp. i vých. Slovenska: Mali zme staros_to predat' (Turecká BB) - Já soN_čakala na možnozd'veN_sa dostat’ (Lapáš NIT) - Každi ma pravo sebe vibrac (Dlhá Lúka BAR).

Na rozdiel od spisovnej slovenčiny býva v nárečiach infinitívny atribút aj pri konkrétnych substantívach. Príklady: Pletávam košíki sedid’repu, sečku fsípat', takie (Chlebnice DK) - Dostala som takie topánki na gombičku zapinat (Pribiš DK) - Bielopotočäñi robä osli ostrit kosi (Podbiel TRS) - Mladeñec podaroval defke brošňe na blusku zapnut' (Bobrov NÁM) - varexa haluški ociezat (Ludrová RUŽ) - Mali zme takú lampu na stuol položit' (Háj MAR) - Toto je košíkkukuricu lámat' (Lúčnica $\mathrm{n}$. Žit. VRB) - Čil robíN_zaz_metle dvor zametat' (Maňa VRB) - Tu máme málo miésta visázat stromi (Trenč. Závada TRČ) - Eśćik som teraz rog do lesa šla na take haluźe ohňa roskladac (Prešov).

Infinitívnym atribútom sa zároveň vyjadruje, na aký ciel' slúži vec pomenovaná nadradeným substantívom. Tento sprievodný význam však neobsahujú výpovede, v ktorých má substantívum podradené infinitívu funkciu príslovkového určenia. Porovnaj: varexa haluški ociezat 'na ociedzanie halušiek'; metla dvor zametat' 'na zametanie dvora' oproti topáyki na gombičku zapinat 'zapínané na gombičku'; lampa na stuol položit' 'stolová lampa'.

Infinitívny atribút pri konkrétach je nateraz najbohatšie doložený z oravských nárečí. O tom, že je to aktívny prvok jazykového inventára ich nositelov, svedčí aj spojenie lopata sádzat chleby v umeleckej próze oravského rodáka Antona Habovštiaka.

V staršej slovenčine sa s infinitívnym atribútom pri konkrétnych substantívach stretáme najmä v historických písomnostiach majetko-právneho charakteru, akými sú testament, súpis pozostalosti, dedičské vysporiadanie, súpis hospodárskeho inventára a podobne. Porovnaj: tabla gedlo nosyti (Bystrička1725) - ssest sstety praczu česat (Nitra 1737) - nebožece ucha kolesam vrtat (1774 Modrý Kameň) ${ }^{3}$.

Údaje o fungovaní infinitívneho atribútu v nárečiach na Morave poskytujú práce Věry Michálkovej (1971), Jana Balhara (1974), Stanislava Králíka (1984) a Mileny Šipkovej (1993). Podla V. Michálkovej (1971: 124) je vo východomoravských nárečiach stav zhodný sa stavom $\mathrm{v}$ spisovnej češtine, kde býva infinitívny atribút len pri abstraktach (pozri Grepl, Karlík 1986: 269). S. Králík (1984: 124) ho na západnejšie ležiacej kelčskej nárečovej oblasti tiež zachytil iba v spojení

\footnotetext{
3 Doklady sú z diel Pramene k dejinám slovenčiny, s. 88; HSSJ III 442; HSSJ IV 167.
} 
s abstraktami. J. Balhar (1974: 53) uvádza, že v lašských nárečiach stáva infinitívny atrbút nielen pri substantívach abstraktného významu, ale - hoci zriedkavejšie - aj pri substantívach konkrétnych. Vtedy zároveň vyjadruje, na čo vec pomenovaná nadradeným substantívom slúži ${ }^{4}$. M. Šipková (1993: 75-76) pokladá atributívne infinitívy pri konkrétnych substantívach $\mathrm{v}$ hanáckych nárečiach za špecificky nárečové konštrukcie a upozorňuje na ich hojný výskyt pri substantívach vo funkcii slovesno-menného prísudku

V ukrajinčine je infinitívny atribút bezpríznakovým prostriedkom spisovnej syntaxe aj pri konkrétach - tak napr. v názvoch máp v ukrajinskom nárečovom atlase (AUM) 'журавель витягати воду' (I, m. 295), 'торба годувати коней' (I, m. 299), 'діжка квасити капусту та овочі' (II, m. 54), 'кварта пити воду' (II, m. 284), ‘бабка клепати косу' (III, čast' 1., m. 93), 'знаряддя обрабляти конопляне волокно' (III, čast' 1., m. 77) ${ }^{6}$.

V časti stredoslovenských a okrajovo aj v časti severzápadoslovenských nárečí konštrukcii typu „košík repu kopat", teda syntaktickej štruktúre $\mathbf{S}-\mathbf{I n f}+\mathbf{S}_{\text {Acc }}$ konkuruje konštrukcia typu „košík na repu kopat" so syntaktickou štruktúrou $\mathbf{S}$ - praep $\mathbf{S}_{\text {Acc }}+\mathbf{I n f}$, ktora vznikla skrížením typu `košík na repu< $x$ >košík repu kopat‘. Poradie komponentov tohto typu nezhodného atribútu - na rozdiel od typu ‘košík repu kopat‘ - je fixné.

Príklady: Poziemki sa dobré na čaj na želúdog_liečit (Čimhová TRS) Robím košíki na seno znášad'_zo šopa, menšie košíki na repu kopat, aj takí pre dieta nosid'do pola som uplietou (Chlebnice DK) -Zbieram aj takuo lista na visib_opkladat' (Ratkovo MAR) - Mali putňe pre kravi napájat' (Socovce MAR) - nuož na šuĐku rezat' (Veličná DK) - habarka na mlïeko rostrepat', dỉenko pod hrňiec položit' (Slov. Pravno MAR) - železná okúvačka na kosu kut (St. Hory $\mathrm{BB})$ - zakalag_na sviňu zaklat' (Stará Bystrica KNM).

Citované práce o syntaxi moravských nárečí tento variant nezhodného atribútu neuvádzajú.

Vo východoslovenských nárečiach sa vo funkcii nezhodného atribútu pri substantíve s konkrétnym významom ešte sporadicky vyskytuje archaická konštrukcia so štruktúrou $S-\boldsymbol{c o}+\operatorname{Inf}+S_{\mathrm{Acc}} / \mathrm{Adv}$. Stredná generácia používatelov tamojších nárečí ju už vníma ako zanikajúcu.

Príklady: Zme pletli perka co mascic kolače (Kokšov-Bakša KOŠ) - Mal remin co britev bruśic (Porúbka GIR) - Kupilam sebe chustku co na chribed_uviazaic. (Bracovce $\mathrm{MCH})$ - Za jednu korunku bula taka xustočka co na hlavu nośic. (Trhovište MCH) - Vecka treba štrikačku co štrikaz_hrozno (Kazimír TRB).

\footnotetext{
4 Por. Balhar 1974: 53: každy mjeł trupku jeden na druheho trubič; to je taška nakupovač.

Por. Šipková 1993: 76: to nebela ženská f polo delat; to je chlap skale lámat.

6 O infinitívnom atribúte v južnoruských dialektoch pozri Собинникова 1961: 147.
} 
Ako obdobu tohto typu infinitívneho atribútu hodnotíme ukrajinskú nárečovú konštrukciu typu bapka ščob kosy klapat', doloženú z okolia Charkova (AUM III, čast' 1., mapa 93 'бабка (клепати косу)', bod 70).

$\mathrm{Na}$ zachovávanie starej väzby substantíva verbale s akuzatívom, zhodnej $s$ väzbou určitých slovesných tvarov, poukázal už J. Stanislav v monografii o liptovských nárečiach (porov. Stanislav 1932: 447). Väzba substantíva verbale s akuzatívom vo funkcii nezhodného atribútu je aj v súčasnosti vysoko produktívna vo väššine nárečí južnostredoslovenskej skupiny, v systéme nárečí severostredoslovenskej skupiny tiež patrí k živým, no menej častým syntaktickým prostriedkom. Západoslovenským a východoslovenským nárečiam je neznáma.

Príklady: Bes košíka na repu sézaňá bi sa ňezaobišieu na jar (Chlebnice DK) - Nosila som peňiaze za seno vozeňia (Lipt. Ján LM) -Tam volade stojí kobilina na drevo rezaňía (Uhorská Ves LM) - Mali zme objednáunke na kapce pleteñia (Králiky $\mathrm{BB}$ ) - Robiu som aj varexe na haluške viberaňía (Nemecká BRE) - Druhon_kúte bolo oprieto maštalnuo ohrablo, vile na hnoj kidañia (Čelovce $\mathrm{MK})$ - Su lojtri na drevo vozeñia a na seno vozeňía lojtri (Hnúšta RS) - sitko na krumple pretláčañia (Brezno) - pílka na gróti rezañia (Ban. Bystrica) - šeliake príprauke na lekvár vareňia (Podsitnianska BŠ) - koníg_na drevo pílenia (Ban. Štiavnica) - robote okolo maku dorábäňia (Čelovce MK) ${ }^{7}$.

V súčasnej fáze výskumu sa nám javí, že v severnej časti stredoslovenských nárečí majú vyššiu frekvenciu syntaktické konštrukcie s infinitívnym atribútom, t. j. typ „košík repu kopat“ a typ „košík na repu kopat“. Tieto typy sme v centrálnej časti nárečí južnostredoslvenskej skupiny nezachytili.

Determintívne sklady typu „koník na drevo pílenie“ spomínané monografie o moravských dialektoch neevidujú.

O silnej pozícii štruktúry praep $\mathbf{S}+$ SVerb v južnostredoslovenských nárečiach svedčí aj skutočnost', že sa používa vo funkcii viacerých rozvíjajúcich vetných členov, napr. ako príslovkové určenie ciela: $\mathrm{Na}$ pupok povíjaňi ia bou potrebnei povojňíg_zdľ̌e eneho rífa (Čelovce MK) - Prišla (suseda) aj na kukuricu moržuvaňia (Čelovce MK) - To je iba na hlavu boleňia (Detva ZVO) - Išli volat po dediňe krsnie matke na rúxo obliekaňia (Priechod BB); príčiny: Ja idem prati hábei za to drevo dovezeňia (Lešt MK); predmetu: Každi musí pristúpid'_na poriadog_udržiavañia (Detva ZVO)

Hojné doklady na túto konštrukciu vo funkcii nezhodného atribútu poskytujú historické pamiatky stredoslovenskej proveniencie. Ilustračné príklady: pyla na desky pylenia welika (Zvolen 1669) - na cesto valanja tabla drevena (Bystrička 1725) - troge krosan na platno tkanya (s. l. 1737) - hamriki na kosu kuvangia,

7 O stredoslovenskom sufixe - $i a$ (na Orave $-a ̈,-a ́,-a$ ) v tvare nom.-akuz. bjo-kmeňov p. Pauliny 1990: 77 a nasled. 
liehy na sudy skladanga (M. Kameň 1774) (porov. Majtán, Skladaná 1992: 38, 91; HSSJ 2: 118, 145, 218).

Výsledky sondačného prieskumu geografickej situácie nezhodného prívlastku vyjadreného rozvitým infinitívom a substantívom verbale z celého územia slovenského jazyka nás utvrdzujú v názore, že podstatnú čast̉ archívu východiskových údajov pre syntaktický zväzok Atlasu slovenského jazyka treba vybudovat' pomocou bohatej excerpcie vybraných syntaktických javov z rozsiahleho súboru súvislých nárečových textov, rovnomerne rozložených po celom slovenskom jazykovom teritóriu. Takto sa zistí nielen inventár a územný rozsah rovnoznačných syntaktických prostriedkov, ale ich frekvencia naznačí aj ich postavenie $\mathrm{v}$ súbore syntaktických prostriedkov.

\section{Bibliografia}

Atlas slovenského jazyka red. Jozef Štolc, Ferdinand Buffa, Anton Habovštiak, t. 1-4, Bratislava 1968-1984.

Balhar Jan, 1974, Skladba lašských nářečí, Praha.

Buffa Ferdinand, 2004, Slovník šarišských nárečí, Prešov.

Ferenčíková Adriana, 1986, Časové podradovacie súvetie v slovenských nárečiach, Bratislava.

Ferenčíková Adriana, 2009, Spracovanie syntaxe slovenských nárečí metódami jazykového zemepisu, [w:] História, súčasný stav a perspektívy dialektologického bádania, „Jazykovedné štúdie“, t. XXVI, s. 32-37.

Grepl Miroslav, Karlík Petr, 1986, Skladba spisovné češtiny, Praha.

HSSJ - Historický slovník slovenského jazyka, red. Milan Majtán, t. I-VII, Bratislava 1991-2008.

Inventár syntaktických javov v slovenských nárečiach, 1974, zostavil Ján Oravec a Adriana Ferenčíková (čast’ o časových vetách), Bratislava.

Králík Stanislav, 1984, Nářečí na Kelečsku, Praha.

Majtán Milan, Skladaná Jana (zost.), 1992, Pramene k dejinám slovenčiny, Bratislava. Michálková Věra, 1971, Studie o východomoravské nářeční věte, Praha.

Pauliny Eugen, 1990, Vývin slovenskej deklinácie, Bralislava.

Ružička Jozef, 1958, Skladba neurčitku v slovenskom spisovnom jazyku, Bratislava.

Stanislav Ján, 1932, Liptovské nárečia, Turčiansky Sv. Martin.

Šipková Milena, 1993, Stavba věty v mluvených projevech (Syntax hanáckých nářečí), Jinočany.

Štolc Jozef, 1961, Ku koncepcii atlasu slovenského jazyka, „Jazykovedný časopis“, t. XII, s. $159-176$.

Štolc Jozef, 1967, Výsledky, perspektívy a problémy slovenskej dialektológie, „Slovenská reč”, t. XXXII, s. 216-224.

АУМ - Атлас української мови. Том первий 1984; Том другий 1988; Том третій 2001, Кийів. 
Собинникова Валентина И., 1961, Простое предложение в русских народных говорах, Воронеж.

\section{Orientačné lokalizačné značky:}

\author{
BB - Banská Bystrica \\ BŠ - Banská Štiavnica \\ BRE - Brezno \\ DK - Dolný Kubín \\ GIR - Giraltovce \\ KNM - Kysucké Nové Mesto \\ KOŠ - Košice \\ LM - Liptovský Mikuáš \\ MAR - Martin \\ $\mathrm{MCH}$ - Michalovce
}

\author{
MK - Modrý Kameň \\ NÁM - Námestovo \\ NIT - Nitra \\ RS - Rimavská Sobota \\ RUŽ -Ružomberok \\ TRB - Trebišov \\ TRČ - Trenčín \\ TRS - Trstená \\ VRB - Vráble \\ ZVO - Zvolen
}

\section{Streszczenie}

Do badań geograficznego zróżnicowania składni gwarowej metoda gromadzenia danych terenowych za pomocą kwestionariusza nie jest efektywna. Właściwą informację o systemowych strukturach syntaktycznych w dialektach można zdobyć tylko dzięki analizie obszernego kompletu tekstów gwarowych, równomiernie obejmujących ogólnonarodowe terytorium językowe. Na takiej analizie opierają się nasze badania typów przydawki bezokolicznikowej (na p. metla dvor zametat; košíki na repu kopat; xustočka co na hlavu nośic) i przydawki niekongruentnej ze substantivum verbale (na p. varexe na haluške viberaňia; robote okolo maku dorábäňia), które należą do systemu syntaktycznego wielkiej części gwar słowackich, jednak nie istnieją w języku literackim. 